\title{
Vivat selvmordsforebygging, en verdifull tjueåring
}

\author{
Av Ann-Jorid Moller, Johan Lindmark og Dag Willy Tallaksen
}

\section{SAMMENDRAG}

Vivat Selvmordsforebygging (Vivat) har arbeidet i Norge i 20 år. Verdimessige grunnantakelser som respekt og omsorg for enkeltmennesker samt troen på at selvmord kan forhindres via opplæring, har stått sentralt i alle disse årene. Vivat er tilstede over hele landet, våre 170 kursledere har så langt hatt mer enn 50000 deltakere på våre kurs. På denne måten har Vivat trolig vært med på redusere tabu og å gjøre våre lokalsamfunn bedre beskyttet mot selvmord.

\section{Vivat Selvmordsforebygging (Vivat) has operated in} Norway for 20 years. Our core beliefs such as respect and care for individuals and that suicide can be prevented through education have been central in all these years. Vivat is available throughout the country with its 170 trainers. 50,000 participants have so far completed our workshops. In this way, Vivat has possibly been important in reducing taboo and making our communities suicide safer.
Per satt foran meg, det var som hele skikkelsen var sunket sammen. Han mumlet: «Det er ikke no'n vits, jeg orker ikke mer!» Som kontaktlærer hadde jeg hatt flere samtaler med denne eleven, og med hans foresatte. Håpløsheten stod formelig skrevet i ansiktet på gutten. Ulike tilrettelegginger var igangsatt og flere var involverte i saken. I det siste hadde amperheten i Per stilnet og foreldrene var forsiktige optimister. At Per var roligere, giorde situasjonen enklere både på skolen og hjemme. Her vi nå satt sammen for en ny prat, opplevde jeg likevel en større uro enn noen gang tidligere. Tankene mine raste; «Tenker Per på selvmord? Jeg kan jo ikke spørre han, for tenk om jeg overtolker. Enn om jeg gir eleven min en virkelig dårlig idé i all min hjelpsomhet?»
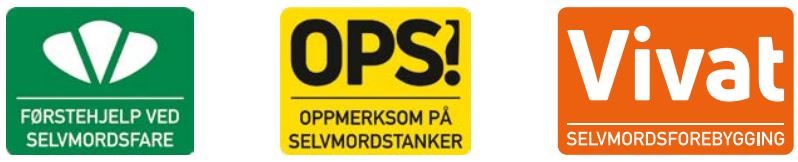

SKAL MAN SPøRRE OM SELVMORD? Kan hvem som helst lære seg å spørre om selvmord? Og, hva giør man dersom svaret på et slikt spørsmål er ja? Vivat har levert kurs i førstehjelpskompetanse ved selvmordsfare giennom 20 år. Gjennom vår opplæring har mange kursdeltakere fått svar på spørsmål som ligner tankene til læreren i innledningen. Kursdeltakerne får blant annet delta på praktiske øvelser med særlig vekt på hvordan spørre om selvmord og hvordan hjelpe. I kursene Førstehjelp ved selvmordsfare og Oppmerksom på selvmordstanker beveger vi oss i det vi kaller et førstehjelpsperspektiv, der målet er å berge livet her 


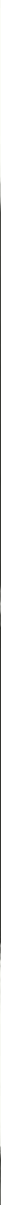

og nå. Vårt mål er at læreren kunne uttrykt sin bekymring og spurt Per direkte om selvmord. Kanskje kunne læreren også vært en førstehjelper med kjennskap til ressurser for videre hielp. Vi har grunn til å tro at slik intervension virker forebyggende (Mann et al., 2005).

Artikkelen vil løfte frem det vi mener er de viktigste pilarene for organisasjonen Vivat selvmordsforebygging, videre vil vi vise omfanget av vår kursing i dag, før vi tilslutt retter blikket fremover.

\section{Fra vesentlige oppfatninger og grunnantakelser til verdier}

Vivat selvmordsforebygging, heretter også Vivat, ble for tjue år siden tuftet på spesifikke grunnantakelser om selvmord, selvmordsforebygging og opplæring innen tematikken, hentet fra LivingWorks sitt kurs ASIST (LivingWorks, 2019). I prosessen med språklig oversetting samt faglig og kulturell tilpasning var det nødvendig med en dyp forståelse av hva som lå i tenkingen rundt ASIST. Den norske ordlyden skulle både harmonere med originaltenkningen, og samtidig fungere under norske forhold. Den solide jobben som ble giort fra starten av har fortsatt og er blitt vårt grunnlag for en felles forståelse for selvmord, som også kommer til uttrykk i vår aktivitet. På mange måter kan våre vesentlige oppfatninger og grunnantakelser sammenlignes med en organisasjons verdier. Operasjonalisering av verdier er en viktig prosess som må finne sted for at verdiene ikke bare skal forbli en rekke honnørord, men komme til uttrykk i praksis (Kirkhaug, 2018). I dag kan vi se at Vivat sine vesentlige oppfatninger og grunnantakelser er solide verdier som fungerer som en stødig plattform for organisasjonen og for de valg som må tas knyttet til hvordan vi driver opplæring innen et utfordrende tema.

\section{Grunntanker om selvmord, selvmordsforebygging og opplæring}

Vivat har etter hvert jobbet frem vesentlige oppfatninger og grunnantakelser i forhold til selvmord og selvmordsforebygging generelt, og i forhold til hvordan vi best lærer andre å bli førstehjelpere. Denne grunnlagstenkningen vies plass både i opplæringen og i kvalitetssikringen av Vivat kursledere. Selvmord er et samfunnsproblem og det må helhetlig innsats til for god forebygging (Helsedirektoratet, 2014). I denne sammenheng er en viktig grunnantakelse hos Vivat at intervensionsferdigheter kan læres. En annen er at mange mennesker kan få opplæring i intervensjonsferdigheter. Samfunnet bør inneha ulike typer hjelpere som har et felles språk og kan samarbeide, for å være mer beskyttet mot selvmord. Gode, tilgiengelige kurs innen førstehjelp ved selvmordsfare virker både som bevisstgiøring og opplæring, og vi vet hvordan vi metodisk kan lære bort intervensjonsferdigheter til mange. For Vivat er individperspektivet viktig. Vi onsker mindre fokus på forutbestemte oppfatninger om hvem som kan eller ikke kan komme i selvmordsfare. Đnsket om å søke hielp 
oppmuntres av en åpen, direkte og ærlig samtale om selvmord. Vi er opptatte av at hjelperen skal oppdage og komme personen i selvmordsfare sine behov imøte. Relasionen mellom personen i selvmordsfare og hielperen er av stor betydning. Vivat sin opplæring bygger på kunnskap om at de fleste personer med selvmordstanker er usikre når det gielder selvmord som en mulig utvei i en svært vanskelig situasjon (Shneidman, 1994). Oppmerksomhet på selvmord og trygghet til å kunne lytte og snakke med en person i selvmordsfare vil kunne være med å utsette selvmordshandlingen slik at annen hielp også kan komme til.

Respekt og omsorg er kanskje de to viktigste grunnverdiene, og disse kan vi relatere både til opplærings- og hjelpesituasjonen. Respekt handler om å se på deltakeren sine tanker, holdninger, erfaringer og kunnskaper som betydningsfulle bidrag for felles læring. Vi kan se en parallell mellom respekt som grunnverdi og forholdet mellom hielper og personen i selvmordsfare. En respektfull tilnærming kan bygge ned stigma og tabuer knyttet til selvmord og anerkjenne motet personen i selvmordsfare viser med å dele sine tanker om selvmord. Omsorgsbegrepet i vår opplæringssammenheng handler om å skape en trygg setting, der vi også tar på alvor at alle mennesker kan komme i selvmordsfare. En omsorgsfull kursleder gir dessuten en viktig modellering for hvordan en hjelper viser omsorg i arbeidet med å trygge situasjonen i sitt møte med en person i selvmordsfare.

Balanse mellom trygghet og utfordring skaper økt læring, og er også sentralt i relasjonen mellom hjelper og person i selvmordsfare. Ved å balansere graden av trygghet og utfordring i opplæringen, vil deltakerne dele erfaringer og våge å prøve nye ferdigheter (Vivat Selvmordsforebygging, 2016). Det kan føles overveldende å bli utfordret på å skulle være en førstehjelper ved selvmordsfare, men vi ser at terskelen for å bruke kompetansen bygges ned når man har fått giort seg erfaringer i en trygg setting. I en hielpesituasion må man alltid vurdere forholdet mellom utfordring og trygghet. Noen ganger møter hielper en person med selvmordstanker som har stor indre smerte og kaos, og det er umiddelbar fare for liv, mens i andre hjelpesituasjoner vil det være aktuelt at personen med selvmordstanker selv kan bidra til å finne ut hva som trengs for å beskytte livet. Trygghet vil alltid komme først, og når det er mulig vil personen i selvmordsfare ha nytte av å bidra med innspill på hva som skal til for at situasionen kan trygges her og nå.

Vivat sine vesentlige oppfatninger og grunnantakelser om selvmord og selvmordsforebygging brukes aktivt. Denne verdibaserte grunnstrukturen kan ses

\section{Antall kursdeltakere utvalgte år}

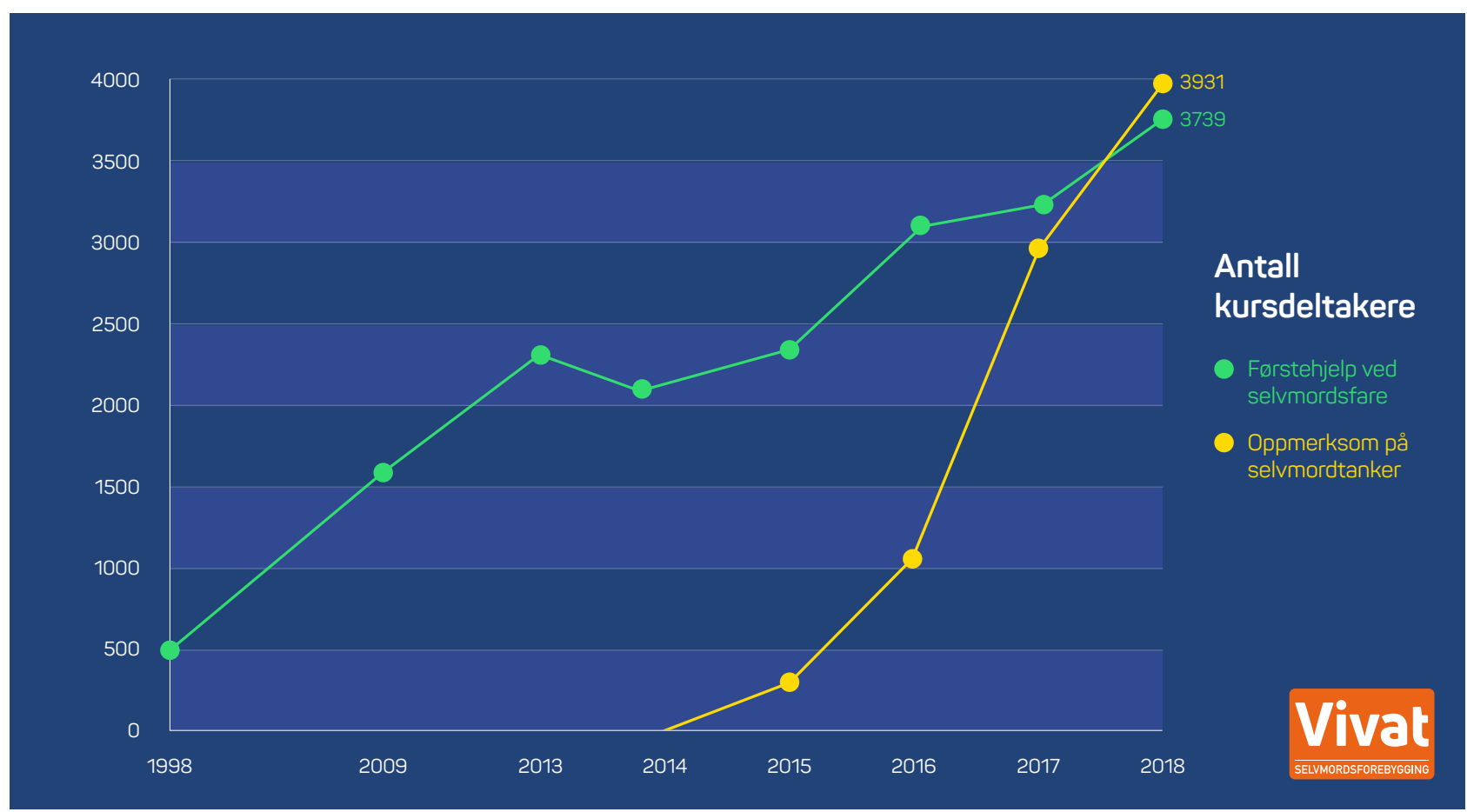

Våre kurs gjennomføres med fokus på kunnskap, erfaringsutveksling og øvelser. Gruppestørrelsen er maksimalt 15 per kursleder på Førstehjelp ved selvmordsfare og 30 på kurset Oppmerksom på selvmordstanker! Vi ser at OPS har en meget raskt økning i kursdeltakere, og vi ser også at Førstehjelp ved selvmordsfare samtidig fortsetter med fin økning av kursdeltakere. 
som en sterk faktor i forhold til å bestå som organisasjon og drive god opplæring. En annen viktig faktor er organisasjonens oppbygning, hvor fokuset hele tiden har vært på kvalitetssikring giennom støtte, veiledning og faglig påfyll i alle ledd. (Les mer om organisasjonsstrukturen i faktaboksen.)

\section{Vivat nå og i fremtiden}

Siden oppstart i 1998 har Vivat gitt ulike hielpere kompetanse til å spørre om selvmord og til å kunne gripe inn for å minske den umiddelbare selvmordsfaren. Vivat startet i Nord-Norge, men har siden år 2000 vært et landsdekkende tilbud. Mer enn 50 ००० deltakere har vært på kurs hos Vivat selvmordsforebygging. Vivat har i dag om lag 170 kursledere fordelt over hele landet, og veiledere plassert i alle helseregioner. Hovedadministrasion er lokalisert i Tromsø på Universitetssykehuset Nord-Norge, og oppdraget løses giennom at Vivat utdanner og kvalitetssikrer lokale kursledere som kan levere kurs til befolkningen.

Vivat selvmordsforebygging har giennom tiue år bygd opp en solid organisasjon bestående av veiledere og kursledere. Vivat har to ganger blitt evaluert på oppdrag av Helsedirektoratet. Begge ganger med positivt resultat, senest i november 2019 av BDO. Vi er der befolkningen er, vi kjenner landets svært varierte geografi, og er lokalkjent med fylker og kommuner. På den måten kan vi raskt nå ut med kompetanse der den trengs. Vi har spesialisert oss på opplæring «ansikt til ansikt» i kontrollerte gruppestørrelser. Vi tror at dette er viktig for at deltakeren skal oppnå ny eller forbedret handlingskompetanse. Vivat har evaluert alle sine kurs siden oppstart. Den umiddelbare evalueringen viser svært fornøyde kursdeltakere som gierne anbefaler kurset videre. Vivat har erfaring med å giennomføre større revisjoner og lære opp kursledernettverket på en effektiv måte (Tallaksen \& Lindmark, 2015). Vi ønsker å bruke vårt landsdekkende nettverk og utvikle nye kurstilbud i fremtiden.

Lokalsamfunnet blir trolig bedre beskyttet mot selvmord ved mer åpenhet rundt selvmord, kombinert med at vi øker samfunnets evne til å oppdage selvmordstanker (WHO, 2014). Det trengs hielpere på ulike nivå, og de bør vite av hverandre. Vivat onsker fremover å være en aktør som i samarbeid med lokalsamfunnet/ kommuner/etater/bedrifter og organisasjoner finner ut hvilken type opplæring som er riktig for det enkelte sted. Kanskje vil det være hensiktsmessig med differensiert opplæring, og at det enkelte miljø får hjelp til å lage sin egen strategi som kan tre i kraft når selvmordstanker oppdages. Samarbeid bør ikke være et festtalebegrep, men settes ut i praksis giennom at

\section{Kurssteder i Norge 2018}

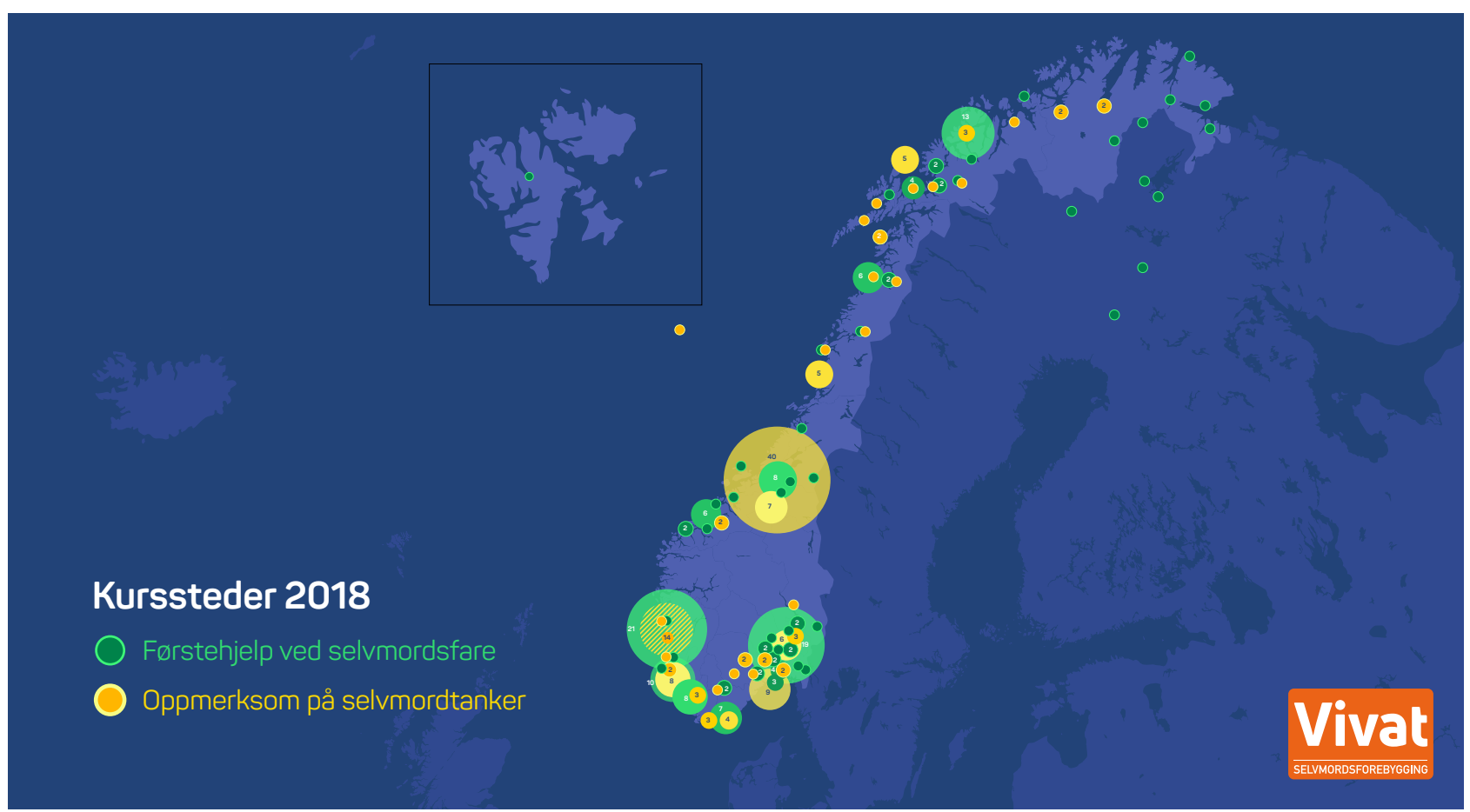

Vivat når ut over hele landet, og kursledere med lokalt kjennskap er med på gjøre sitt nærsamfunn mer beskyttet i forhold til selvmord. Blant kurssted i 2018 var både Svalbard og fartøy til havs representert. 
ulike selvmordsforebyggende miliøer samarbeider godt. Eksemplet med Per, som artikkelen startet med, var virkeligheten for forfatteren for femten år siden og den er nok dessverre fremdeles slik mange steder. Lærerens (og alles) barriere for å spørre om selvmordstanker må bygges ned, - fordi Per, (og alle) med selvmordstanker trenger det!

Vivat har en verdibasert organisasjonskultur der vi er opptatt av å løfte hverandre og leve som vi lærer. En slik organisasjonskultur er resultat av målrettet og systematisk arbeid med grunnantakelsene som vi har jobbet med helt fra begynnelsen for tiue år siden. Vi utnytter paralleller mellom modellen for hvordan hielpe en person i selvmordsfare og hvordan vi utdanner våre kursledere, og dette gienspeiles også i formidlingen til våre kursdeltakere. Det har bidratt til tiue spennende år hvor et stadig økende antall kursdeltakere har gitt tilbakemeldinger om okt handlingskompetanse. Vivat bidrar gierne i mange år til med å oke folks kunnskap om selvmordsforebygging. Tjue år er ingen alder!

\section{FAKTA OM VIVAT}

Vivat selvmordsforebygging er et av Helsedirektoratets selvmordsforebyggende tiltak, og oppdraget er å kurse landets befolkning samt lære opp kursledere som kan spre kompetansen videre i sine lokalsamfunn. Vivat er forankret ved Universitetssykehuset Nord-Norge og har hovedkontor i Tromsø. Vivat har kurslederne spredt rundt i landet og disse har sin nærmeste støtte i regionalt plasserte veiledere. Flere av veilederne til Vivat er tilknyttet landets Regionale ressurssenter om vold, traumatisk stress og selvmordsforebygging (RVTS). Landets øvrige selvmordsforebyggende miljøer og organisasjoner er viktige for oss. Mange av disse har også egne kursledere utdannet av Vivat og benytter kursene våre som en del av sitt kompetansetilbud. Vivat har siden 2003 vært nært knyttet til Forsvaret og deres selvmordsforebyggende tiltak, gjennom opplæring av kursledere og bruk av våre kurs.

Kursene Førstehjelp ved selvmordsfare, (med oppfriskningskurset FriskOpp) og Oppmerksom på selvmordstanker, er designet av LivingWorks Education (LW) i Canada. Vivat har kontraktsfestet rett til oversetting, tilrettelegging og bruk av kursene i Norge. De internasjonale navnene på kursene er henholdsvis ASIST, TuneUp og safeTALK. Vivat har også et tilbud for behandlere som jobber med pasienter med selvmordserfaringer. Kurset Suicide to Hope presenteres på norsk, men benytter originalt, engelsk kursmateriell. Samarbeidet med LivingWorks Education (LW) i Canada er fortsatt viktig for oss. LW står for kvalitet og jevnlig revisjon av kursene.

Les mer på www.vivatselvmordsforebygging.net og www.livingworks.net

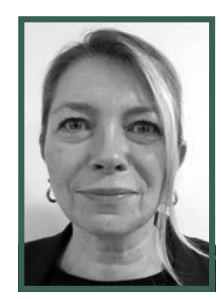

ANN-JORID MØLLER, leder for Vivat selvmordsforebygging.

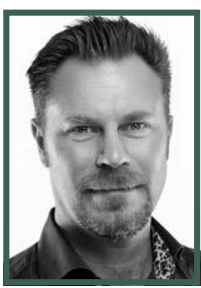

JOHAN LINDMARK, veileder/utdanningsansvarlig i Vivat selvmordsforebygging og spesialrådgiver RVTS-Øst.

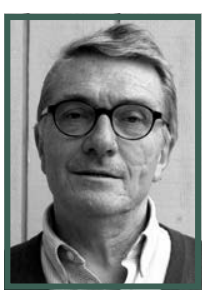

DAG WILLY TALLAKSEN, Førstelektor ved OsloMet og veileder i Vivat selvmordsforebygging.

\section{REFERANSER:}

BDO (2019). Rapport. Evaluering av Vivat selvmordsforebygging for Helsedirektoratet.

Helsedirektoratet. (2014). Handlingsplan for forebygging av selvmord og selvskading. (IS 2182). Oslo Retrieved from https://helsedirektoratet.no/ Lists/Publikasjoner/Attachments/117/Handlingsplan-for-forebygging-avselvmord-og-selvskading-2014-2017-IS-2182.pdf

Kirkhaug, R. (2018). Verdibasert ledelse (2. utg. ed.). Oslo: Universitetsforl. LivingWorks. (2019). LivingWorks ASIST. Retrieved from https://www.livingworks.net/asist

Mann, I.I., Apter, A., Bertolote, I., Beautrais, A., Currier, D., Haas A. .... Hendin, H. (2005). Suicide prevention strategies: a systematic review. IAMA 294 (16), 2064-74

Shneidman, E. S. (1994). Definition of suicide. Northvale, N.|: I. Aronson.

Tallaksen, D. W., \& Lindmark, I. (2015). Det trengs mange og handlekraftige (forste) hielpere! Suicidologi, 20(3).

Vivat Selvmordsforebygging. (2016). Forstehielp ved selvmordsfare. Kursledermanual. Tromsø: Vivat Selvmordsforebygging.

WHO. (2014). Preventing Suicide. A global imperative. Geneva Retrieved from http://apps.who.int/iris/bitstream/10665/131056/1/9789241564779_ eng.pdf 